\title{
EARLY RETIREMENT: FreE CHOICE OR FoRCED DECISION?
}

\author{
DAVID DORN \\ ALFONSO SOUSA-POZA
}

CESIFO WORKING PAPER No. 1542

CATEGORY 4: LABOUR MARKETS

SEPTEMBER 2005

An electronic version of the paper may be downloaded

- from the SSRN website:

www.SSRN.com

- from the CESifo website:

www.CESifo-group.de 


\title{
EARLY RETIREMENT: FREE CHOICE OR FORCED DECISION?
}

\begin{abstract}
Early retirement is usually explained as a supply-side phenomenon. However, early retirement can also be a demand-side phenomenon arising from a firm's profit maximization behavior. This paper analyzes voluntary and involuntary early retirement based on international microdata covering 19 industrialized countries. The results indicate that generous early retirement provisions of the social security system do not only make voluntary early retirement more attractive for individuals, but also induce firms to encourage more employees to retire early. In particular, firms seem to use early retirement to reduce staff during economic recessions and as a means to circumvent employment protection legislation.
\end{abstract}

JEL Code: J14, J21, J22, J26.

Keywords: early retirement, involuntary early retirement, social security, pensions.

\author{
David Dorn \\ FAA-HSG \\ Guisanstr. 92 \\ 9000 St. Gallen \\ Switzerland \\ David.Dorn@alumni.unisg.ch
}

Alfonso Sousa-Poza

FAA-HSG

Guisanstr. 92

9000 St. Gallen

Switzerland

alfonso.sousa-poza@unisg.ch

Previous versions of this paper were presented at the 4th Meeting on Social Security and Complementary Pension Systems, Lisbon, Portugal, 2005, at the CEBR/CESifo Conference on Pension Reform, Copenhagen, Denmark, 2005, and at the UK Department of Work and Pensions WPEG Conference in York, Great Britain, 2005. We thank the participants of these conferences for their comments. Moreover, we want to thank Monika Butler, Robert Hutchens and Philip Taylor for helpful comments and Robert Duval for providing data. The usual disclaimer applies. 


\section{Early Retirement: Free Choice or Forced Decision?}

\section{Introduction}

The trend toward earlier retirement has been one of the most important labor market developments in the past fifty years. During this period, participation rates of older workers have fallen in virtually all OECD countries. The decrease in labor market participation implies considerable economic costs, particularly through social security benefit payments and a lower tax base.

A large body of economic literature has analyzed early-retirement behavior from a laborsupply perspective. According to this literature, workers' retirement decision is based on an assessment of future streams of wages and pension payments from public and private sources. The optimal retirement date is chosen in order to maximize a worker's future expected utility. Examples for such life-cycle retirement models are the contributions by Burkhauser (1979), Gordon and Blinder (1980), Mitchell and Fields (1982), Burtless (1986), and Gustman and Steinmeier (1986). An important theoretical prediction of this theory is that earlier and more generous availability of public old-age benefits will increase the incidence of early exits from the labor force because early retirement becomes a more attractive choice for the individuals. Indeed, international comparisons such as those by Blöndal and Scarpetta (1998) or Duval (2003) find that early retirement is more prevalent in countries with more generous early retirement regulations. Furthermore, Gruber and Wise (1999) show for various countries that retirement tends to take place around the age when early retirement benefits can be claimed.

The effects of labor demand on early retirement have received far less attention. Classical theory predicts that firms should pay their workers their marginal product and should have no incentive to induce early retirement. Although Lazear (1979) does not explicitly address the issue of early retirement, his analysis provides both a supply- and demand-side explanation of the institution of mandatory retirement. In his moral hazard model, employers and employees agree to a contract that pays younger workers wages below their VMP (value of marginal product), and older workers more than their VMP. Due to moral hazard, such contracts assure that workers' lifetime VMP is larger than in the absence of such contracts. However, a necessary condition for such payment schemes is mandatory retirement, i.e., a date at which a worker is no longer entitled to receive a wage greater than his VMP. Stern $(1987,1994)$ shows that, if a worker's position affects utility and/or productivity, then a firm can induce its 
workers to retire before their marginal product equals their reservation wage. In essence, older works have better jobs which are more productive and provide the most position utility. Retirement of an older worker implies that a younger worker can be promoted, thus becoming more productive, enjoying greater position utility and, as a result, requiring lower wages in order to remain at the firm. In the same line of theory, Hutchens (1999) develops an implicit contract model in which early retirement also arises out of firms' profit maximization behavior. Firms actively use wage and pension structures to influence or even determine workers' retirement decisions. Particularly, as a response to adverse demand shocks, firms choose to direct workers toward early retirement. In fact, the option of continuing work might be so restricted by firms that workers no longer perceive their early retirement as an individual choice, but as a forced decision. ${ }^{1}$ In accordance with the supply-side theory, the model by Hutchens (1999) also predicts that higher early retirement benefits increase the incidence of early retirement. However, this is not caused by the fact that more workers choose to retire early, but by the fact that firms increasingly push workers into early retirement. Social security benefits can act as a form of unemployment insurance, effectively subsidizing workforce reductions by lowering the cost to the firm of shedding older workers. In other words, generous social security provisions for early retirement might have the undesirable effect of reducing employment and creating involuntary early retirement instead.

Although sufficient anecdotal evidence on the importance of the phenomenon of involuntary early retirement exists (e.g. Schmähl 2003 for the case of Germany), we are not aware of empirical studies that document the extent and determinants of involuntary early retirement. ${ }^{2}$ This is particularly true in a cross-national setting - a setting that is essential when trying to assess the role national regulations (e.g. in the field of social security or employment protection legislation) on early retirement behavior. The main contribution of this paper is to provide international evidence on the extent to which early retirement is involuntary and on the factors that influence the ratio of voluntary to involuntary early retirement. This is done by analyzing a unique international microdata set covering 19 countries. Our results show that the extent to which early retirement is involuntary varies greatly among countries. While

1 Throughout this paper, we sometimes use the terms 'involuntary' or 'forced' early retirement when referring to a situation where a worker retires due to restrictions on continuing employment. While a firm can not literally force a worker to retire, workers are likely to perceive a retirement as forced when they no longer have access to employment at an acceptable wage. In fact, the empirical analysis of this paper shows that many early retirees assess their early retirement as being "not by choice".

2 In a recent study that analyzes a related topic, Hakola and Uusitalo (in press) showed that the introduction of an experience-rating for early retirement benefits in Finland decreased the unemployment risk of older workers. They interpret their results as evidence that firms encourage their workers to retire early in order to reduce or renew the workforce. 
rising unemployment rates and strict employment protection legislations increase the share of involuntary retirements among the early retirees, more generous social security systems do not lead to a higher portion of voluntary early retirements.

The paper is structured as follows: Section 2 provides the theoretical background of the empirical analysis. It summarizes both a basic life-cycle model of supply-side retirement and Hutchens' (1999) model of demand-side-driven retirement. This model is particularly illustrative for explaining the reasons for involuntary early retirement. Section 3 defines and describes early retirement in an international context. Section 4 discusses the data and methodology used in this study. Section 5 presents the results of the analysis on the voluntary and involuntary retirement and section 6 concludes.

\section{The Classical Life-Cycle Model and Hutchens' Implicit Contract Model}

In a review of the early literature on the retirement decision, Mitchell and Fields (1982) summarize the basic structure of supply-side models of retirement that use a life-cycle framework. A worker has a utility $\mathrm{U}$ which is a positive function of the lifetime consumption vector $\mathbf{C}$ and the lifetime leisure vector $\mathbf{L}: \mathrm{U}=\mathrm{U}(\mathbf{C}, \mathbf{L})$. Consumption increases with income $\mathbf{Y}$, where income depends on earnings $\left(E_{1}, E_{2}, \ldots, E_{R}\right)$ until retirement at time $R$ and on pension benefits $\left(\mathrm{P}_{\mathrm{R}+1}, \mathrm{P}_{\mathrm{R}+2}, \ldots, \mathrm{P}_{\mathrm{T}}\right)$ in the remaining years of life: $\mathrm{Y}=\mathrm{Y}\left(\mathrm{E}_{1}, \mathrm{E}_{2}, \ldots, \mathrm{E}_{\mathrm{R}}, \mathrm{P}_{\mathrm{R}+1}, \mathrm{P}_{\mathrm{R}+2}, \ldots\right.$, $\left.\mathrm{P}_{\mathrm{T}}\right)$.

The public and/or private pensions $P_{t}$ are an increasing function of the retirement date $R$ and an aspect of working $\mathbf{W}$ that increases pension benefits: $\mathrm{P}_{t}=\mathrm{P}_{\mathrm{t}}(\mathrm{R}, \mathbf{W})$ for all periods $t$. $\mathbf{W}$ can be an aspect of work such as years of employment or contributions to a pension plan, and it is a nondecreasing function of lifetime labor $\mathbf{H}: \mathbf{W}=\mathrm{W}(\mathbf{H})$. The lifetime labor supply vector $\mathbf{H}$ and the lifetime leisure vector $\mathbf{L}$ sum up to a constant time endowment $\mathbf{c}$. Consequently, total life-cycle utility can be expressed as

(1) $U=U\left\{C\left[E_{1}, \ldots, E_{R}, P_{R+1}(W(\mathrm{~L}), R), \ldots, P_{T}(W(\mathrm{~L}), R)\right], \mathrm{L}\right\}$

The worker maximizes utility by choice of a labor supply path $\mathbf{H}$, which specifies the retirement date $\mathrm{R} . \mathbf{H}=\mathbf{c}-\mathbf{L}$ is an increasing function of the lifetime streams of earnings $\mathbf{E}$, pensions $\mathbf{P}$, and possible other explanatory variables $\mathbf{X}$ : $\mathbf{H}=\mathrm{H}(\mathbf{E}, \mathbf{P}, \mathbf{X})$.

Some testable predictions of this theory with regard to the choice of the retirement date, which we will consider in the empirical part of the paper, are

1) An exogenous and uniform increase of public or private pensions lowers the retirement age due to equally directed substitution and wealth effects. 
2) If the present value of lifetime pension benefits falls when retirement is delayed, the worker has an incentive to retire earlier. In an extreme case, the pension benefit of every period t might not increase with additional work, i.e., $\frac{\delta P_{t}}{\delta \mathrm{H}}=\frac{\delta P_{t}}{\delta \mathrm{W}} * \frac{\delta \mathrm{W}}{\delta \mathrm{H}}=0$.

3) An exogenous increase of the worker's earnings has ambiguous effects on the choice of retirement. The resulting wealth effect suggests an earlier retirement, but the substitution effect favors a later retirement. However, if the worker starts with an exogenous level of wealth $\mathrm{A}$ and his consumption $\mathrm{C}$ depends positively on $\mathrm{A}$, an increase in wealth unambiguously leads to an earlier retirement.

The supply-side approach to retirement has proved very valuable in explaining many empirical observations regarding retirement. Moreover, the life-cycle model provides the flexibility to accommodate further aspects of the retirement decision in more sophisticated versions of the model. ${ }^{3}$ However, the limitation of this class of models is that they tend to treat the behavior of the employer in a cursory way.

A different approach that highlights the employer's influence on worker's retirement behavior is the model proposed by Hutchens (1999). He developed an implicit contract model of early retirement with two actors: a risk-neutral firm and a risk-averse worker. The worker's risk aversion and the desire for consumption smoothing assures that the firm will enter into a three-period contract with the worker and thereby raising its profits.

Under this contract, the worker is employed in the first period, either employed or early retired in the second period, and nonemployed in the third period. Employment status is hence only uncertain in the second period, where an early retirement can take place.

The worker lives for two periods with certainty and has an exogenous probability s of surviving to the third period. His expected lifetime utility is the sum of expected utility in the three periods (with no discounting). If he is employed, he has utility $\mathrm{U}\left(\mathrm{w}_{\mathrm{i}}\right)$, where $\mathrm{w}_{\mathrm{i}}$ is the wage in period $i$. In case of retirement, the utility is $U\left(b_{i}+g_{i}+z_{i}\right)$, where $b_{i}$ is a period $i$ private pension payment, $\mathrm{g}_{\mathrm{i}}$ is a old-age pension payment of the government's social security program and $z_{i}$ is the period i consumption value of home production. The period values of $z_{i}$ are $z_{1}=0, z_{3}=z_{m}$, and $z_{2}$, which is only revealed at the beginning of the second period and has a known distribution $\mathrm{f}\left(\mathrm{z}_{2}\right)$ for $0 \leq \mathrm{z}_{2} \leq \mathrm{z}_{\mathrm{m}}$.

If the worker retires only in period three, he will receive a social security benefits $g_{3}$ in that period. In case of an early retirement in period 2, the worker will get a social security benefit

3 Extended models can for instance include investment decisions (e.g. Kingston 2000) or family considerations (e.g. Gustman and Steinmeier 2000). 
$\mathrm{g}_{2}$ in both the second and third period. Actuarial adjustments of social security benefits are represented by specifying this social security benefit as $g_{2}=g_{3}-\Delta$. If there is no actuarial adjustment, then $\Delta=0$ and if the system is actuarially fair, then $g_{2}+\operatorname{sg}_{2}=\operatorname{sg}_{3}=s\left(g_{2}+\Delta\right)$, i.e., $\Delta=\mathrm{g}_{2} / \mathrm{s}$. As the third-period social security benefits depend on second period employment status, so does third-period private pensions. Let $b_{3}^{1}$ and $b_{3}^{0}$ be the third-period private pensions for individuals that were employed and early retired in the second period, respectively.

The worker has two possible marginal products, $\theta(H)$ and $\theta(L)$ with $\theta(H)>\theta(L) \geq 0$ and $\theta(L)<\mathrm{z}_{\mathrm{m}}$. The first-period and the last-period marginal product is $\theta(H)$ and $\theta(L)$, respectively; the lower marginal product in period three is due to aging. As for the secondperiod value of home production, the marginal product in period 2 only becomes known to the firm and the worker at the beginning of that period. The realization of $\theta_{2}$ depends on the demand for the firm's products which determines the its second-period technology and hence the extent to which the worker's skills will match the technology. The marginal product in period 2 will take a value of $\theta(L)$ in case of a demand shock, and a value of $\theta(H)$ if no such shock occurs. Both scenarios are assumed to have a probability of 0.5.

Letting $\mathrm{p}_{2}$ denote the probability that the worker is employed in period 2 , the expected utility of the worker is hence as follows:

$$
\begin{aligned}
& E U=\sum_{i=1}^{3} E U_{i} \\
& E U_{1}=U\left[w_{1}\right] \\
& E U_{2}=0.5 \sum_{\theta_{2}=\theta(L)}^{\theta_{H}} \int_{z}\left\{p\left(\theta_{2}, z_{2}\right) U\left[w_{2}\left(\theta_{2}, z_{2}\right)\right]+\left[1-p\left(\theta_{2}, z_{2}\right)\right] U\left[b\left(\theta_{2}, z_{2}\right)+g_{2}+z_{2}\right]\right\} f\left(z_{2}\right) d z_{2} \\
& E U_{3}=0.5 \sum_{\theta_{2}=\theta(L)}^{\theta_{H}} s \int_{z}\left\{p\left(\theta_{2}, z_{2}\right) U\left[b_{3}^{1}+g_{2}+\Delta+z_{m}\right]+\left[1-p\left(\theta_{2}, z_{2}\right)\right] U\left[b_{3}^{0}+g_{2}+z_{m}\right]\right\} f\left(z_{2}\right) d z_{2}
\end{aligned}
$$

The firm's expected profit $\pi$, which is the sum of its expected profits over the three periods, can be denoted as:

$$
\begin{aligned}
& \pi=\sum_{i=1}^{3} \pi_{i} \\
& \pi_{1}=\theta_{1}(H)-w_{1}(1) \\
& \pi_{2}=0.5 \sum_{\theta_{2}=\theta(L)}^{\theta_{H}}\left\{\left[\theta_{z}-w\left(\theta_{2}, z_{2}\right)\right] p\left(\theta_{2}, z_{2}\right)-b\left(\theta_{2}, z_{2}\right)\left[1-p\left(\theta_{2}, z_{2}\right)\right]\right\} f\left(z_{2}\right) d z_{2} \\
& \pi_{3}=0.5 \sum_{\theta_{2}=\theta(L)}^{\theta_{H}} s \int_{z}\left\{-p\left(\theta_{2}, z_{2}\right) b_{3}^{1}-\left[1-p\left(\theta_{2}, z_{2}\right)\right] b_{3}^{0}\right\} f\left(z_{2}\right) d z_{2}
\end{aligned}
$$


Workers and firms negotiate a three-period contract over wages, private pensions, and employment probabilities. The firm chooses the variables $\mathrm{w}_{1}, \mathrm{w}\left(\theta_{2}, \mathrm{z}_{2}\right), \mathrm{p}\left(\theta_{2}, \mathrm{z}_{2}\right), \mathrm{b}\left(\theta_{2}, \mathrm{z}_{2}\right)$, and $b_{3}$ to maximize its total profit subject to the constraint that the worker's total expected utility must not be smaller than the (exogenous) utility that he could obtain from a job elsewhere in the market. The result of the firm's profit maximization is that a worker's employment status in the second period is determined by the following decision rule:

$$
\begin{aligned}
& \text { If } \theta_{2} \geq \mathrm{z}_{2}+g_{2}-\Delta s \text {, then } \mathrm{p}\left(\theta_{2}, \mathrm{z}_{2}\right)=1 \\
& \text { If } \theta_{2}<\mathrm{z}_{2}+g_{2}-\Delta s \text {, then } \mathrm{p}\left(\theta_{2}, \mathrm{z}_{2}\right)=0
\end{aligned}
$$

An important point to notice in this model is that wages, private pensions and third-period social security benefits do not enter into the early retirement decision. Here, early retirement only results of a firm's profit maximization. While the contract is specified such that the worker will initially voluntarily enter the contract, it is well possible that he will ex-post perceive a company-mandated early retirement according to (4) as being involuntary.

The solution (4) shows that early retirement is affected by the level of social security early retirement benefits and in particular by the extent of actuarial adjustment. If actuarial adjustment is not full, i.e. $\Delta<\mathrm{g}_{2} / \mathrm{s}$, then an increase in social security benefits for early retirees raises the probability of early retirement. The reason for this is that early retirement benefits allows the firm to reduce its second-period private pensions, which in turn reduces the costs of early retirement and thereby increasing the incident of early retirement. If full actuarial adjustment takes place, then payment of social security benefits to early retirees does not affect early retirement. Note that in case of no full actuarial adjustment, the level of early retirement that results from the solution (4) is inefficiently high, since the firm will send employees into early retirement even if their labor product is larger than the marginal value of home consumption. In an extension of this model, it can also be easily shown that a payroll tax that is levied on earnings but not on pensions will further increase the prevalence of early retirement, because the firm's profit when employing the worker will decrease, while the profit in case of early retirement remains unaffected.

This model gives rise to the following hypothesis which will be tested in the empirical part of the paper:

1) A higher level of public early retirement benefits $g_{2}$ leads to more early retirement by subsidizing the firms' workforce reductions.

2) A low actuarial adjustment $\Delta$ of the pensions also contributes to more early retirement.

3) Product-demand shocks induce firms to send employees into early retirement because they decrease workers' labor product $\theta_{2}$. 
While Hutchens' (1999) model explicitly models the firm's behavior, it does not take into account that firms may also have the possibility to lay off workers - a practice often encountered in reality. We therefore propose a further hypothesis:

4) In countries with a rigid employment protection legislation, firm-driven early retirements are more widespread since layoffs are not a readily available alternative for reducing staff.

The comparison of these hypothesis with the predictions of the supply-side theory as described above shows several similarities. In particular, generous early retirement provisions of the social security system are expected to increase early retirement according to both theories. A strength of Hutchens' (1999) model is that it explicitly models how productdemand shocks and the resulting desire of firms to reduce staff affect the employment opportunities of a worker. While supply-side models could in theory accommodate variations in the wages offered to workers, the review article by Hurd (1990) points out that this aspect is often neglected, at least in empirical analysis: "Assuming that the worker could choose hours and years of work freely at the preretirement wage, which is the only one observed for that worker, leads to the incorrect conclusion that the worker retired because of a shift in the position or shape of his indifference curves, when, in fact, he retired because of unobserved employment constraints." (Hurd 1990, p. 597). Conversely, one aspect of the retirement decision that is better reflected by the supply-side models than in the Hutchens (1999) model is the fact that a worker can hardly be "forced" into early retirement in the sense that he is not allowed to search for another job. If there is not only one, but several firms, and if the product-demand shocks affect only some of these firms, the worker might still find a job at attractive conditions. At least in many European countries, however, there is evidence that older employees face considerable difficulties in finding employment. In a comprehensive review of empirical studies from various European countries, Taylor (2001) concludes that employers' attitudes and policies toward older employees imply a strong age discrimination in the labor market, for instance by setting age limits in recruiting. ${ }^{4}$ Consequently, workers exceeding a certain age no longer have attractive employment options with other firms. In such cases, Hutchens' (1999) one-firm model would be applicable.

4 Constraints to the employment of older workers can also stem from regulations of the social security system. For instance, firms in Switzerland have to pay contributions to mandatory private pension funds and the contribution rates increase with the worker's age (see Dorn and Sousa-Poza 2003). 


\section{Data and Definitions}

Before discussing early retirement in more depth, it is useful to clearly define the concept of "retirement" which can have different meanings. According to OECD (1995), three broad definitions of retirement can be distinguished: (i) being a recipient of a public or private oldage pension, regardless of the current employment status; (ii) being out of the labor force, regardless of the reason for ceasing work and no matter whether an old-age pension is being drawn; or (iii) having a self-described status of retired, regardless of employment status and receipt of a pension. These definitions of retirement can easily be transformed into definitions of early retirement if the retirement takes place prior to the individual reaching the legally defined standard retirement age.

In this paper, early retirement is defined based on a combination of the second and third concept. In other words, retirement is a self-declared state and only individuals who are out of the labor force are considered to be retirees.

The international comparison of voluntary and involuntary early retirement is conducted using data from the 1997 International Social Survey Program (ISSP). The ISSP is a continuing annual program of cross-national collaboration which started in 1985. The data are collected by independent institutions in the participating countries using the same questionnaire. The topics of the annual surveys change from year to year. In 1997, 34,835 individuals were interviewed on "Work Orientations", covering issues on work content and organization as well as general attitudes towards work and leisure. Our analysis includes the following 19 countries: Canada, Cyprus, Denmark, France, Germany, Great Britain, Hungary, Italy, Japan, the Netherlands, New Zealand, Norway, Poland, Portugal, Slovenia, Spain, Sweden, Switzerland, and the USA..$^{5}$

As laid out above, the ISSP data allows us to identify individuals who (i) were no longer working and who (ii) assessed their own status as being early retired. Importantly, all early retired persons had to state either "I retired early - by choice" or "I retired early - not by choice". We use this information to define a dichotomous dependent variable having a value equal to one if the respondent retired early in an involuntary manner ("not by choice"), and equal to zero if early retirement was voluntary ("by choice"). This variable is analyzed with a series of probit models. The analysis covers the early retirement of individuals aged 45 to 64 who retired between 1983 and 1997. This broad definition allows for a reasonable sample size

5 Six developing countries from Asia and Eastern Europe were excluded from the analysis because the data set contained very few early retirement observations for these countries. 
of 651 early retirees in the multivariate analysis. Table A1 in the appendix summarizes the corresponding explanatory variables. ${ }^{6}$

In addition to the ISSP variables, our analysis includes variables referring to general economic and social security characteristics of the different countries. These macro-level variables are included to test the theoretical predictions that were discussed in section 2 of this paper. Wealth level as a supply-side determinant of early retirement is represented by a country's real GDP per capita in the year of an individual's early retirement. The data is taken from Penn World Tables (Heston et al. 2002). Product demand shocks, which can trigger early retirement in the framework of Hutchens (1999), are characterized by the increase of the unemployment rate between the year before the retirement and the year of retirement. The data sources for this variable and for the OECD Employment Protection Legislation Index ${ }^{7}$ for the year 1990 are OECD (1999) and (2004b), respectively.

There are two main characteristics of old-age pensions systems that supposedly affect early retirement. First, the expected old-age pension replacement rate at a given age measures the expected pension income as a fraction of the earnings just prior to retirement. The replacement rate can thus be interpreted as an indicator for the generosity of an old-age pension system. ${ }^{8}$ Second, the decrease in accumulated pension wealth accrual measures the reduction in expected lifetime pension income that results from postponing retirement. Such a decline in pension wealth accrual is equivalent to an implicit tax on continued work and is characteristic for a pension system that is actuarially unfair. In an actuarially neutral pension system, pension wealth accrual is invariant to the retirement age. Our models include variables for the average old-age pension gross replacement rate between age 60 and 64 in the year of retirement and for the decrease in accumulated pension wealth accrual when postponing retirement from age 55 to 64 . These variables take into account both public social security pensions and mandatory private pensions. The pension replacement rate data has

6 The main advantage of the ISSP data is that it allows us to identify voluntary and involuntary early retirement in an international setting and on a micro-data level. The limitation of the data is that it is only cross-sectional. We can therefore not identify specific characteristics of individuals' pre-retirement jobs such as occupation. Moreover, it is not possible to readily compare early retired individuals to people who did not retire early since the identification of persons belonging to the latter group is difficult given the lack of information on previous working status (see also Dorn and Sousa-Poza 2005 for a further discussion of this issue).

7 The index refers to the strictness of employment protection for regular employment and is based on a variety of criteria including notice period, amount of severance pay, and definition of unfair dismissal.

8 In a life-cycle framework with certain restrictive conditions, the level of public pensions should have no effect on the choice of a retirement date. This is the case if contributions to the pension system are perceived as savings, if pension benefits paid equal the amount of contributions paid, and if the interest rate equals the rate of growth of total wages. 
been provided by Romain Duval (part of this data is published in Duval, 2003, p. 39), while the pension wealth accrual data is taken from Blöndal and Scarpetta $(1998$, p. 65$) .{ }^{9}$

\section{Incidence of Involuntary Early Retirement}

The incidence of involuntary early retirement varies considerably among countries, as shown in table 1. In the USA and in Denmark, only one out of ten early retirees has involuntarily moved into retirement. Other countries with very low rates of forced early retirement are Canada, Japan, and Norway. Conversely, involuntary early retirement seems to be the rule rather than the exception in some continental European countries. In Germany, Portugal, and Hungary, more than half of all early retirements are not by choice.

Clearly, these large differences in the incidence of involuntary early retirement call for an explanation. Based on the theory of Hutchens (1999), we would expect that a large extent of company-driven early retirements may be the cause for involuntary retirements. This hypothesis will be tested in section 5 .

Research on the self-declared motives for early retirement also suggests that, apart from the desire to leave work and company restructurings, poor health is among the most important causes for early retirement (see, e.g., Burtless and Quinn (2000) for the United States and Dorn and Sousa-Poza (2004) for Switzerland). At least some of the retirees who leave the labor force due to poor health might assess their retirement as involuntary. While our data does not allow us to control for individual health, it does not seem plausible that major differences in health levels among the countries in our sample should exist. Therefore, public health can hardly explain the large inter-country variance in the proportion of involuntary early retirements.

9 Duval (2003) computed the pension replacement rates are a synthetic indicator based on six individual cases with different wage levels and different marital status. Pension wealth accruals reported by Blöndal and Scarpetta (1998) are computed based on singles with average wages. The macro-level variables are summarized in table A1 in the appendix. Note that some of the OECD variables are not available for four countries in our sample (Cyprus, Hungary, Poland, Slovenia). The multivariate analysis will hence be restricted to the remaining 15 countries. 
Table 1: Involuntary Early Retirements as a Percentage of all Early Retirements and Early Retirees per Worker

\begin{tabular}{lcc}
\hline Country & $\begin{array}{c}\text { Percentage of Involuntary Early } \\
\text { Retirement }\end{array}$ & $\begin{array}{l}\text { Early Retirees per Worker, age } \\
\text { group 45-69 }\end{array}$ \\
\hline Hungary & $62.1 \%$ & 0.342 \\
Portugal & $54.2 \%$ & 0.165 \\
Germany & $50.0 \%$ & 0.183 \\
Slovenia & $46.3 \%$ & 0.344 \\
France & $41.0 \%$ & 0.081 \\
Poland & $40.4 \%$ & 0.269 \\
Sweden & $37.5 \%$ & 0.093 \\
Spain & $32.5 \%$ & 0.328 \\
Great Britain & $28.9 \%$ & 0.247 \\
Italy & $28.6 \%$ & 0.174 \\
New Zealand & $26.2 \%$ & 0.109 \\
Switzerland & $20.5 \%$ & 0.118 \\
Cyprus & $17.1 \%$ & 0.175 \\
Netherlands & $16.7 \%$ & 0.300 \\
Japan & $15.9 \%$ & 0.033 \\
Norway & $13.0 \%$ & 0.062 \\
Canada & $12.2 \%$ & 0.196 \\
United States & $9.4 \%$ & 0.080 \\
Denmark & $8.8 \%$ & 0.132 \\
\hline
\end{tabular}

Source: Based on ISSP 1997 data. Countries are sorted by the first data column.

The exception to this rule might be the Eastern European countries. According to Szalai (1991), retirement in Hungary - the country with the highest ratio of involuntary early retirement in our sample - has predominantly been caused by poor health, which is widespread among workers. Szalai (1991) argues that this is because the previous state economy had many jobs with physically demanding and sometimes hazardous working conditions. Indeed, the high ratios of involuntary early retirement across all Eastern European countries in the sample suggest that the economic structures between 1983 and 1997, which covered both a period of state economy and the transition to a market economy, have led to a pattern of early retirement different to those in Western European or North American countries. A relatively low standard of living even for well-educated individuals implied that few people had the financial resources that facilitate a voluntary early retirement. Moreover, it is plausible that the economic transition that took place in Eastern Europe in the 1990s produced a large number of company-driven forced early retirements in the course of privatizations and reorganizations of state-owned companies. The high incidence of involuntary early retirement in Eastern Europe can hence possibly be explained by economic circumstances that led to a high number of retirements for health and company reasons, while the probability of voluntary early retirements was low. 
However, even when focusing on a more homogeneous sample of countries with wellestablished industrialized market economies, as we will do in the econometric analysis in section 5, large differences in the incidence of involuntary early retirement remain. ${ }^{10}$

In addition to the incidence of involuntary early retirement, table 1 also contains a measure for the general prevalence of early retirement (both voluntary and involuntary) in the respective countries. This measure is the ratio of early retirees per active worker in the age group 45 to 69. Again, large international differences can be observed. In Hungary, Slovenia, and Spain, this early retirement ratio exceeds 0.3 , while there are less than 0.1 early retired persons per active worker in the United States, Japan, or Norway.

Table 2: Correlations between Ratio of Involuntary Early Retirement, Early Retirees per Worker, and Labor Force Participation Rate

\begin{tabular}{|c|c|c|c|}
\hline & $\begin{array}{c}\text { Ratio of Involuntary } \\
\text { Early Retirement }\end{array}$ & $\begin{array}{l}\text { Early Retirees per } \\
\text { Worker }\end{array}$ & $\begin{array}{l}\text { Labor Force } \\
\text { Participation Rate } \\
\text { (age 55-64) }\end{array}$ \\
\hline \multicolumn{4}{|l|}{ Pearson Correlation } \\
\hline $\begin{array}{c}\text { Ratio of Involuntary } \\
\text { Early Retirement }\end{array}$ & $\begin{array}{c}1.000 \\
(n=19)\end{array}$ & $\begin{array}{c}0.461 * * \\
(\mathrm{p}=0.047, \mathrm{n}=19)\end{array}$ & $\begin{array}{c}-0.518 * * \\
(\mathrm{p}=0.033, \mathrm{n}=17)\end{array}$ \\
\hline $\begin{array}{l}\text { Early Retirees per } \\
\text { Worker }\end{array}$ & & $\begin{array}{c}1.000 \\
(n=19)\end{array}$ & $\begin{array}{c}-0.728 * * * \\
(\mathrm{p}=0.001, \mathrm{n}=17)\end{array}$ \\
\hline $\begin{array}{l}\text { Labor Force } \\
\text { Participation Rate } \\
\text { (age 55-64) }\end{array}$ & & & $\begin{array}{c}1.000 \\
(n=17)\end{array}$ \\
\hline \multicolumn{4}{|c|}{ Kendall's Tau-b Correlation } \\
\hline $\begin{array}{c}\text { Ratio of Involuntary } \\
\text { Early Retirement }\end{array}$ & $\begin{array}{c}1.000 \\
(n=19)\end{array}$ & $\begin{array}{c}0.287^{*} \\
(\mathrm{p}=0.068, \mathrm{n}=19)\end{array}$ & $\begin{array}{c}-0.529 * * * \\
(\mathrm{p}=0.003, \mathrm{n}=17)\end{array}$ \\
\hline $\begin{array}{l}\text { Early Retirees per } \\
\text { Worker }\end{array}$ & & $\begin{array}{l}1.000 \\
(n=19)\end{array}$ & $\begin{array}{c}-0.324^{*} \\
(\mathrm{p}=0.070, \mathrm{n}=17)\end{array}$ \\
\hline $\begin{array}{l}\text { Labor Force } \\
\text { Participation Rate } \\
\text { (age 55-64) }\end{array}$ & & & $\begin{array}{l}1.000 \\
(\mathrm{n}=17)\end{array}$ \\
\hline
\end{tabular}

Sources: Ratio of Involuntary Early Retirement and Early Retirees per Worker based on ISSP 1997 data, Labor Force Participation Rates based on OECD (2004a). */**/*** denote significance at the $10 \% / 5 \% / 1 \%$-level. Note that the OECD data does not contain participation rates for Cyprus and Slovenia.

Table 2 reports the correlations between involuntary early retirement, early retirement ratios, and labor force participation rates. It is not surprising that there is a highly significant negative correlation between the early retirement ratio and the labor force participation rates of older persons (age 55 to 64), because a high incidence of early retirement has often been

10 Countries excluded from the analysis are Cyprus, Hungary, Slovenia, and Poland, for which some of the aggregate OECD data is not available. 
identified as a cause for low participation rates. A striking result, however, is the significant and relatively sizable positive correlation between the percentage of involuntary early retirement among early retirees and the number of early retirees per worker. Countries with a large proportion of involuntary early retirement also tend to have lower participation rates. These results accentuate the empirical importance of involuntary early retirement, and they establish a link between the relative proportion of involuntary early retirement among early retirees, which will be analyzed in section 5, and the overall incidence of early retirement and labor force participation.

\section{Determinants of Involuntary Early Retirement}

We estimate a series of probit models that analyze the determinants of the probability that an early retirement was involuntary. The sample contains observations referring to early retired persons from 15 OECD member countries. ${ }^{11}$ It includes individuals who went into early retirement between 1983 and 1997 and at ages between 45 and 64. Weights are adjusted to give every country the same weight in the total sample. Furthermore, the Moulton (1990) problem that is associated with estimating the effects of macro-level variables on micro units is taken into account by clustering standard errors by countries using the standard technique described by Froot (1989).

The main focus of the analysis is on the impact of various social security and labor market variables on involuntary early retirement. Notably, we are interested to see whether the results provide support for the presence of demand-side early retirement as proposed by Hutchens (1999). In the framework of this theory, we would expect that favorable early retirement provisions of social security systems (represented by high pension replacement rates and decreasing pension wealth accruals) and adverse economic conditions (represented by increasing unemployment rates) lead to company-driven early retirements, which tend to be involuntary from a worker's perspective. Furthermore, we hypothesize that a more strict employment protection legislation might encourage companies to use forced early retirement as a means of reducing staff.

Conversely, a pure supply-side explanation of early retirement that abstracts from demand-side effects would, all else being equal, predict that a higher level of wealth and

11 Canada, Denmark, France, Germany, Great Britain, Italy, Japan, Netherlands, New Zealand, Norway, Portugal, Spain, Sweden, Switzerland, and the USA. 
favorable early retirement provisions increase the number of persons who voluntarily choose early retirement.

Table 3 shows probit estimations of the determinants of involuntary early retirement. Apart from social security and labor market characteristics, the estimated models (I) to (IV) also control for the socio-demographic factors gender, marital status, and age at retirement, as well as for the year of retirement.

Model (I) in table 3 considers the impact of the socio-demographic variables and national wealth on the probability that an early retirement was involuntary. Gender and marital status do not have significant effects when we allow for a gender-specific impact of marriage by including an interaction term between gender and marriage. ${ }^{12} \mathrm{We}$ also estimated the models (II) to (IV) for both genders separately, but found no gender-specific impact of the institutional variables. ${ }^{13}$

It is not surprising that early retirements at age 45 to 59 are more often involuntary than retirements at age 60 to 64 . A voluntary early retirement only becomes an attractive option once an individual has had enough time to accumulate a sufficient level of private and public pension wealth to fund consumption in old age. The variables for retirement years do not show a clear trend in the proportion of involuntary early retirement, although the share of forced early retirement in 1995 to 1997 is significantly larger than in the reference period 1983 to 1985.

12 Several empirical studies such as Pozzenbon and Mitchell (1989) or Peracchi and Welch (1994) have found that married women tend to retire earlier than married men, possibly because "married women appear to value nonwork years highly" (Pozzenbon and Mitchell 1989, p. 20).

13 The gender-specific results are not shown here because they yield little additional insights. These results are available from the authors upon request. 
Table 3: Probit estimations of the determinants of involuntary early retirement in 15 countries

\begin{tabular}{|c|c|c|c|c|c|c|c|c|}
\hline \multirow[b]{3}{*}{ Intercept } & \multicolumn{8}{|c|}{ Dependent Variable: Involuntary Early Retirement ( $=1$ if early retirement was involuntary, $=0$ if early retirement was by choice) } \\
\hline & \multicolumn{2}{|c|}{ Model (I) } & \multicolumn{2}{|c|}{ Model (II) } & \multicolumn{2}{|c|}{ Model (III) } & \multicolumn{2}{|c|}{ Model (IV) } \\
\hline & 0.716 & $(0.501)$ & $0.776^{*}$ & $(0.516)$ & 0.143 & $(0.655)$ & 0.211 & $(0.695)$ \\
\hline Female & -0.171 & $(0.305)$ & -0.180 & $(0.306)$ & -0.160 & $(0.298)$ & -0.164 & $(0.305)$ \\
\hline Married & -0.130 & $(0.190)$ & -0.146 & $(0.191)$ & -0.167 & $(0.185)$ & -0.162 & $(0.189)$ \\
\hline Female x Married & -0.183 & $(0.340)$ & -0.183 & $(0.340)$ & -0.177 & $(0.335)$ & -0.186 & $(0.339)$ \\
\hline Retirement age $55-59$ & $0.475 * * *$ & $(0.124)$ & $0.474 * * *$ & $(0.136)$ & $0.473 * * *$ & $(0.116)$ & $0.488 * * *$ & $(0.129)$ \\
\hline Retirement age $50-54$ & $0.613^{* * *}$ & $(0.183)$ & $0.600 * * *$ & $(0.190)$ & $0.676^{* * *}$ & $(0.195)$ & $0.675^{* * *}$ & $(0.206)$ \\
\hline Retirement age $45-49$ & $0.612 * *$ & $(0.267)$ & $0.571 * *$ & $(0.270)$ & $0.691 * *$ & $(0.273)$ & $0.688 * *$ & $(0.287)$ \\
\hline Early retired in $1995-1997$ & $0.527^{*}$ & $(0.280)$ & $0.559 * *$ & $(0.280)$ & $0.539^{*}$ & $(0.302)$ & $0.551 *$ & $(0.321)$ \\
\hline Early retired in 1992-1994 & 0.145 & $(0.256)$ & 0.151 & $(0.247)$ & 0.036 & $(0.246)$ & 0.032 & $(0.256)$ \\
\hline Early retired in $1989-1991$ & 0.280 & $(0.268)$ & 0.312 & $(0.263)$ & 0.281 & $(0.269)$ & 0.285 & $(0.275)$ \\
\hline Early retired in $1986-1988$ & -0.051 & $(0.339)$ & -0.029 & $(0.343)$ & -0.017 & $(0.320)$ & -0.003 & $(0.361)$ \\
\hline $\begin{array}{l}\text { Real GDP p.c. (year of } \\
\text { retirement) }\end{array}$ & $-0.090 * * *$ & $(0.015)$ & $-0.094 * * *$ & $(0.015)$ & $-0.072 * * *$ & $(0.019)$ & $-0.074 * * *$ & $(0.022)$ \\
\hline $\begin{array}{l}\text { Average pension gross } \\
\text { replacement rate (age 60-64) }\end{array}$ & & & -0.158 & $(0.226)$ & & & -0.251 & $(0.197)$ \\
\hline $\begin{array}{l}\text { Decrease of pension wealth } \\
\text { accrual (age } 55 \text { to age } 64 \text { ) }\end{array}$ & & & $0.047 * *$ & $(0.023)$ & & & 0.024 & $(0.025)$ \\
\hline $\begin{array}{l}\text { Change of unemployment } \\
\text { rate (year of retirement) }\end{array}$ & & & & & $0.115^{* *}$ & $(0.048)$ & $0.121 * * *$ & $(0.046)$ \\
\hline $\begin{array}{l}\text { OECD employment } \\
\text { protection legislation index }\end{array}$ & & & & & $0.099 * *$ & $(0.043)$ & $0.102 *$ & $(0.059)$ \\
\hline Number of observations & & & & & & & & \\
\hline Log pseudo-likelihood & & & & & & & & \\
\hline \multicolumn{9}{|c|}{ Wald tests for joint insignificance } \\
\hline \multirow{2}{*}{\multicolumn{3}{|c|}{$\begin{array}{l}\text { Pension gross replacement rate }=\text { pension wealth accrual }=0 \\
\text { Average unemployment rate }=\text { Employment protect. legislation }=0\end{array}$}} & \multirow{2}{*}{\multicolumn{2}{|c|}{$6.47 * *$}} & & & \multicolumn{2}{|c|}{2.04} \\
\hline & & & & & \multicolumn{2}{|c|}{$10.65 * * *$} & \multicolumn{2}{|c|}{$10.14 * * *$} \\
\hline
\end{tabular}

Notes: The reference person is male, unmarried, and has retired between age 60 and 64 and between the years 1983 to 1985 . Standard errors are clustered by country and shown in parenthesis.

Observations are weighted with "federal" weights that give each country the same weight in the total sample. The Wald statistics have Chi-square distributions with 2 degrees of freedom. */**/*** denotes significance at the 10/5/1-percent level. 
An increasing level of wealth is, according to Burtless and Quinn (2000), the most powerful explanation for the trend to earlier retirement that most industrialized countries experienced during the past 50 years. The reason for this is that voluntary early retirement has become more affordable. In the international sample, we find that higher national wealth levels are indeed associated with a larger share of voluntary early retirement.

Model (II) adds the two variables referring to the generosity of the early retirement provisions of the public (or mandatory private) old-age pensions. In accordance with the supply-side theory of retirement, a higher pension gross replacement rate tends to increase the share of voluntary early retirement (this effect is, however, not significant at conventional levels). Conversely, a high decrease in pension wealth accrual between age 55 and age 64, which indicates an actuarially unfair pension system, is associated with a larger share of involuntary retirement. This result is at odds with a pure supply-side perspective of early retirement that explains the positive impact of generous social security systems on early retirement solely with larger incentives for a voluntary retirement. Instead, this finding lends support to the theory of Hutchens (1999) which states that favorable early retirement provisions (such as little actuarial adjustment to early retirement benefits) increase the inclination of firms to encourage workers to retire early.

In model (III), the impact of labor market conditions on involuntary early retirement is considered. The proportion of involuntary retirement is significantly higher in years with increasing unemployment rates. For the case of Switzerland, Dorn and Sousa-Poza (2004) have previously shown that there is parallel movement of the unemployment rate and the portion of early retirement that is due to company reorganizations. Such findings are consistent with the theory of Hutchens (1999) according to which firms promote early retirement when they are confronted with adverse demand shocks, such as in an economic recession.

One aspect that is not fully covered by this theory, however, is the question why companies should prefer the option of forced early retirement to layoffs, although a firmfinanced early retirement program (that possibly includes extraordinary pension payments to retirees) can be costly. Certainly, forced early retirements are often better accepted than layoffs by a company's employees, labor unions, and the public. But apart from these considerations, in some countries, early retirement may, due to strict employment protection legislation, be the only feasible option for reducing (senior) staff. This hypothesis is indeed supported by the results of model (III) which show a positive impact of the OECD employment protection legislation index on the share of involuntary early retirement. 
A specific example of an early retirement practice that reacts to employment protection legislation is Germany's "59 provision" (see, e.g., Schmähl, 2003): because of legal difficulties to layoff older workers, employers offer severance packages to workers who "agree" to give up their jobs. The jobless older individuals then first receive unemployment benefits for at least a year before moving into early retirement at age 60, when unemployed people become entitled to public old-age pensions. This example documents how a relatively rigid employment protection legislation (and generous early retirement provisions of the social security system) can lead to an increased use of forced early retirement by companies in order to circumvent this law.

In model (IV), where both social security and labor market variables are included, employment protection legislation and the change of the unemployment remain significant positive determinants of forced early retirement with almost unchanged coefficient values. These results support the notion of demand-side effects on early retirement as predicted by Hutchens (1999). The impacts of the social security variables on the proportions of involuntary and voluntary early retirement are insignificant and the hypothesis that the pension replacement rate and pension wealth accrual variables have coefficients equal to zero cannot be rejected (as indicated by a Wald test). Using the same variables and a nearly identical sample of countries, the OECD studies by Blöndal and Scarpetta (1998) and Duval (2003) have found that generous provisions of the social security system increase the incidence of early retirement. The results presented here, however, suggest that this increase is not only due to more voluntary, but also due to more involuntary early retirement.

\section{Summary and Conclusions}

In microeconomic theory, early retirement is usually interpreted as a supply-side phenomenon. Increasing wealth and favorable early retirement provisions of public old-age insurances have been identified as causes for early retirement. The fact that a large share of early retirees perceive their retirement as being "not by choice", or involuntary, is difficult to reconcile with purely supply-side explanations. Surprisingly, very few retirement models that explicitly integrate a demand-side perspective can be found in the literature. A noteworthy exception is the theory of Hutchens (1999) which presents a model of a firm that uses social security early retirement benefits as a form of unemployment insurance. The model predicts 
that, in order to reduce staff during economic recessions, companies force individuals into early retirement.

This paper provides an empirical analysis of the impact of social security and labor market characteristics on involuntary early retirement in 15 countries. The results support the notion that involuntary early retirement is an empirically important phenomenon. In some countries, including Germany and Portugal, the portion of early retirees who have not retired by choice is at fifty percent or even higher. Moreover, this percentage tends to be particularly high in countries with low labor market participation rates of older persons.

The empirical analysis shows that increasing unemployment rates and high levels of employment protection legislation encourage involuntary early retirement. This suggests that companies use forced early retirements to reduce staff during economic slowdowns and they make increased use of this measure if it allows them to circumvent rigid employment protection legislation.

While there is considerable previous evidence that more generous early retirement features of social security systems increase the incidence of early retirement, their effect on the proportion of involuntary early retirement is by no means trivial: high replacement rates seem to be associated with more voluntary, and actuarially unfair pension systems with involuntary early retirement. These results are consistent with the interpretation that more generous early retirement features of social security systems can lead to an increase in both voluntary and involuntary early retirements, as individuals face stronger incentives to choose an earlier retirement date, while firms take advantage of the favorable public retirement provisions by forcing more employees into early retirement.

In conclusion, the empirical analysis suggests that, apart form voluntary retirement (which can conveniently be explained by the classic labor-supply models of retirement), some countries are also confronted with a high incidence of involuntary early retirement. In our opinion, demand-side models such as the one by Hutchens (1999) are better suited for explaining such observations. Clearly, early retirement research in these countries should take into account that early retirement is not always the result of a free choice between attractive options, but sometimes the consequence of a forced decision that is strongly influenced by employers' behavior.

Moreover, the results can shed a new light on the welfare effects of generous early retirement provisions of social security systems and more rigid employment protection legislations: while these regulations are intended to be beneficial for workers, they also increase the risk that workers will be forced into early retirement by their employers. 


\section{References}

Blöndal, S., S. Scarpetta (1998): The Retirement Decision in OECD Countries. OECD Economics Department Working Papers No. (98)15. Paris: OECD.

Burkhauser, R.V. (1979): „The Pension Acceptance Decision of Older Workers“, Journal of Human Resources 14(1): 63-75.

Burtless, G. (1986): „Social Security, Unanticipated Benefit Increases, and the Timing of Retirement", Review of Economic Studies 53: 781-805.

Burtless, G. and J.F. Quinn (2000): Retirement Trends and Policies to Encourage Work Among Older Americans. Boston College Working Papers in Economics No. 436. Boston: BCWP.

Dorn, D. and A. Sousa-Poza (2005): „The Determinants of Early Retirement in Switzerland“, Swiss Journal of Economics and Statistics 141(2): 247-283.

Dorn, D. and A. Sousa-Poza (2004): Motives for Early Retirement: Switzerland in an International Comparison. Discussion Paper of the Research Institute for Labor Economics and Labor Law at the University of St. Gallen No. 99. St. Gallen: FAAHSG.

Dorn, D. and A. Sousa-Poza (2003): "Why is the employment rate of older Swiss so high?", Geneva Papers on Risk and Insurance, 28, 652-674.

Duval, R. (2003): The Retirement Effects of Old-Age Pension and Early Retirement Schemes in OECD Countries. OECD Economics Department Working Papers No. (2003)24. Paris: OECD.

Froot, K.A. (1989): „Consistent Covariance Matrix Estimation with Cross-Sectional Dependence and Heteroskedasticity in Financial Data", Journal of Financial and Quantitative Analysis 24(3): 333-355.

Gordon, R.H. and A.S. Blinder (1980): „Market Wages, Reservation Wages, and Retirement Decisions“, Journal of Public Economics 14: 277-308.

Gruber, J. and D.A. Wise (1999): Social Security and Retirement around the World. Chicago: University of Chicago Press.

Gustman, A.L. and T.L. Steinmeier (2000): „Retirement in Dual-Career Families: A Structural Model“, Journal of Labor Economics 18: 503-545.

Gustman, A.L. and T.L. Steinmeier (1986): „A Structural Retirement Model“, Econometrica 54: pp. 555-584.

Hakola, T. and R. Uusitalo (in press): „Not so voluntary retirement decisions? Evidence from a pension reform“, Journal of Public Economics (forthcoming).

Heston, A., R. Summers and B. Aten (2002): Penn World Table Version 6.1, Center for International Comparisons at the University of Pennsylvania (CICUP), October 2002.

Hurd, M.D. (1990): „Research on the Elderly: Economic Status, Retirement, and Consumption and Saving“, Journal of Economic Literature 28(2): 565-637.

Hutchens, R. (1999): „Social Security Benefits and Employer Behavior: Evaluating Social Security Early Retirement Benefits as a Form of Unemployment Insurance“, International Economic Review 40(3): 659-678.

Kingston, G.H. (2000): „Efficient Timing of Retirement“, Review of Economic Dynamics 3: 831-840.

Lazear, E.P. (1979): „Why Is There Mandatory Retirement?“, Journal of Political Economy 87(6): 1261-1284. 
Mitchell, O.S. and G.S. Fields (1982): „The Effects of Pensions and Earnings on Retirement: A Review Essay", in Ehrenberg, R.G. (ed.), Research in Labor Economics, Vol. 5. London: JAI Press.

Moulton, B.R. (1990): „An Illustration of a Pitfall in Estimating the Effects of Aggregate Variables on Micro Units“, The Review of Economics and Statistics 77(2): 334-338.

OECD (2004a): OECD Employment Outlook. Paris: OECD.

OECD (2004b): OECD Labor Force Statistics - Indicators. Online database statistics, version December 15, 2004.

OECD (2002): Labour Force Statistics 1981-2001. Paris: OECD.

OECD (1995): The Transition from Work to Retirement. Social Policy Studies No. 16. Paris: OECD.

Peracchi, F. and F. Welch (1994): „Trends in Labor Force Transitions of Older Men and Women", Journal of Labor Economics, 12(2): 210-242.

Pozzenbon, S. and O.S. Mitchell (1989): „Married Women's Retirement Behavior”, Journal of Population Economics, 2(1): 39-53.

Schmähl, W. (2003): „Ageing Workforce: Firm Strategies and Public Policy in Germany”, Geneva Papers on Risk and Insurance, 28: 575-595.

Stern, S. (1994): „Ability, Promotion, and Optimal Retirement “, Journal of Labor Economics 12(1): 119-137.

Stern, S. (1987): „Promotion and Optimal Retirement“, Journal of Labor Economics 5(4): 107-123.

Szalai, J. (1991): „Hungary: Exit from the State Economy“, in: Kohli, M., Rein, M., Guillemard, A.-M., and van Gunsteren, H. (eds.), Time for Retirement - Comparative Studies of Early Exit from the Labor Force. Cambridge: Cambridge University Press.

Taylor, P. (2001): Analysis of ways to improve employment opportunities for older workers. Report to the European Commission, November 2001. 


\section{Appendix}

Table A1: Definitions and descriptive statistics of variables

\begin{tabular}{|c|c|c|c|c|c|}
\hline $\begin{array}{l}\text { Variable name or } \\
\text { variable group }\end{array}$ & $\begin{array}{l}\text { Definition and source (if other than ISSP } \\
\text { 1997) }\end{array}$ & Mean & S.D. & Min. & Max. \\
\hline $\begin{array}{l}\text { Involuntary early } \\
\text { retirement }\end{array}$ & $\begin{array}{l}1 \text { if early retirement was 'not by choice' / } 0 \\
\text { if early retirement was 'by choice' }\end{array}$ & 0.26 & 0.44 & 0 & 1 \\
\hline Female & 1 if female & 0.39 & 0.49 & 0 & 1 \\
\hline Married & 1 if married & 0.73 & 0.44 & 0 & 1 \\
\hline Female x Married & 1 if female and married & 0.22 & 0.42 & 0 & 1 \\
\hline Retirement age & $\begin{array}{l}1 \text { if retired at age } 60-64 \\
1 \text { if retired at age } 55-59 \\
1 \text { if retired at age } 50-54 \\
1 \text { if retired at age } 45-49\end{array}$ & $\begin{array}{l}0.46 \\
0.38 \\
0.12 \\
0.04\end{array}$ & $\begin{array}{l}0.50 \\
0.49 \\
0.33 \\
0.20\end{array}$ & 0 & 1 \\
\hline Retirement year & $\begin{array}{l}1 \text { if retired in } 1995-1997 \\
1 \text { if retired in } 1992-1994 \\
1 \text { if retired in } 1989-1991 \\
1 \text { if retired in 1986-1988 } \\
1 \text { if retired in } 1983-1985\end{array}$ & $\begin{array}{l}0.30 \\
0.26 \\
0.20 \\
0.14 \\
0.11\end{array}$ & $\begin{array}{l}0.46 \\
0.44 \\
0.40 \\
0.35 \\
0.31\end{array}$ & 0 & 1 \\
\hline $\begin{array}{l}\text { Real GDP p.c. (year } \\
\text { of retirement) }\end{array}$ & $\begin{array}{l}\text { National real GDP per capita in K USD in } \\
\text { year of retirement. Source: Penn World } \\
\text { Tables (Heston et al. 2002). }\end{array}$ & 19.66 & 3.88 & 9.00 & 30.19 \\
\hline $\begin{array}{l}\text { Average pension } \\
\text { gross replacement } \\
\text { rate (age } 60 \text { to age } \\
64)\end{array}$ & $\begin{array}{l}\text { Average gross pension income from public } \\
\text { and mandatory private occupational } \\
\text { schemes between age } 60 \text { and age } 64 \text { for a } \\
\text { person who retired at age } 60 \text { measured for } \\
\text { the individual year of retirement, as a } \\
\text { multiple of pre-retirement annual income. } \\
\text { Computed as an average of six cases with } \\
\text { three different income levels and two } \\
\text { marital statuses. Source: OECD (data } \\
\text { summarized in Duval } 2003 \text {, p. } 39 \text {, } \\
\text { comprehensive data provided by Duval). }\end{array}$ & 0.32 & 0.31 & 0.00 & 0.80 \\
\hline $\begin{array}{l}\text { Decrease of pension } \\
\text { wealth accrual (age } \\
55 \text { to age } 64)\end{array}$ & $\begin{array}{l}\text { Decrease in total pension wealth by } \\
\text { continuing work from age } 55 \text { to age } 65 \text {, as a } \\
\text { multiple of the income at age } 55 \text {. Computed } \\
\text { based on singles with average wages. } \\
\text { Source: OECD (Blöndal and Scarpetta } \\
\text { 1999, p. } 65 \text { ). }\end{array}$ & 1.12 & 1.40 & -0.40 & 7.90 \\
\hline $\begin{array}{l}\text { Change of } \\
\text { unemployment rate } \\
\text { (year of retirement) }\end{array}$ & $\begin{array}{l}\text { Change of the national unemployment rate } \\
\text { between the year before retirement and the } \\
\text { year of retirement in percentage points. } \\
\text { Source: OECD (1999). }\end{array}$ & -0.00 & 1.00 & -2.70 & 4.30 \\
\hline $\begin{array}{l}\text { OECD employment } \\
\text { protection legislation } \\
\text { index }\end{array}$ & $\begin{array}{l}\text { OECD index for rigidity of employment } \\
\text { protection legislation in 1990. Higher } \\
\text { values represent a stricter legislation. } \\
\text { Source: OECD (2004b). }\end{array}$ & 2.40 & 1.23 & 0.20 & 4.10 \\
\hline
\end{tabular}




\section{CESifo Working Paper Series}

(for full list see www.cesifo-group.de)

1477 M. Hashem Pesaran, L. Vanessa Smith and Ron P. Smith, What if the UK had Joined the Euro in 1999? An Empirical Evaluation Using a Global VAR, June 2005

1478 Chang Woon Nam and Doina Maria Radulescu, Effects of Corporate Tax Reforms on SMEs' Investment Decisions under the Particular Consideration of Inflation, June 2005

1479 Panos Hatzipanayotou, Sajal Lahiri and Michael S. Michael, Globalization, CrossBorder Pollution and Welfare, June 2005

1480 John Whalley, Pitfalls in the Use of Ad valorem Equivalent Representations of the Trade Impacts of Domestic Policies, June 2005

1481 Edward B. Barbier and Michael Rauscher, Trade and Development in a Labor Surplus Economy, June 2005

1482 Harrie A. A. Verbon and Cees A. Withagen, Tradable Emission Permits in a Federal System, June 2005

1483 Hendrik Hakenes and Andreas Irmen, On the Long-Run Evolution of Technological Knowledge, June 2005

1484 Nicolas Schmitt and Antoine Soubeyran, A Simple Model of Brain Circulation, June 2005

1485 Carsten Hefeker, Uncertainty, Wage Setting and Decision Making in a Monetary Union, June 2005

1486 Ondřej Schneider and Jan Zápal, Fiscal Policy in New EU Member States - Go East, Prudent Man!, June 2005

1487 Christian Schultz, Virtual Capacity and Competition, June 2005

1488 Yvan Lengwiler and Elmar Wolfstetter, Bid Rigging - An Analysis of Corruption in Auctions, June 2005

1489 Johannes Becker and Clemens Fuest, Does Germany Collect Revenue from Taxing Capital Income?, June 2005

1490 Axel Dreher and Panu Poutvaara, Student Flows and Migration: An Empirical Analysis, June 2005

1491 Bernd Huber and Marco Runkel, Interregional Redistribution and Budget Institutions under Asymmetric Information, June 2005 
1492 Guido Tabellini, Culture and Institutions: Economic Development in the Regions of Europe, July 2005

1493 Kurt R. Brekke and Michael Kuhn, Direct to Consumer Advertising in Pharmaceutical Markets, July 2005

1494 Martín Gonzalez-Eiras and Dirk Niepelt, Sustaining Social Security, July 2005

1495 Alfons J. Weichenrieder, (Why) Do we need Corporate Taxation?, July 2005

1496 Paolo M. Panteghini, S-Based Taxation under Default Risk, July 2005

1497 Panos Hatzipanayotou and Michael S. Michael, Migration, Tied Foreign Aid and the Welfare State, July 2005

1498 Agata Antkiewicz and John Whalley, BRICSAM and the Non-WTO, July 2005

1499 Petr Hedbávný, Ondřej Schneider and Jan Zápal, A Fiscal Rule that has Teeth: A Suggestion for a 'Fiscal Sustainability Council' underpinned by the Financial Markets, July 2005

1500 J. Atsu Amegashie and Marco Runkel, Sabotaging Potential Rivals, July 2005

1501 Heikki Oksanen, Actuarial Neutrality across Generations Applied to Public Pensions under Population Ageing: Effects on Government Finances and National Saving, July 2005

1502 Xenia Matschke, Costly Revenue-Raising and the Case for Favoring Import-Competing Industries, July 2005

1503 Horst Raff and Nicolas Schmitt, Why Parallel Trade may Raise Producers Profits, July 2005

1504 Alberto Bisin and Piero Gottardi, Efficient Competitive Equilibria with Adverse Selection, July 2005

1505 Peter A. Zadrozny, Necessary and Sufficient Restrictions for Existence of a Unique Fourth Moment of a Univariate GARCH(p,q) Process, July 2005

1506 Rainer Niemann and Corinna Treisch, Group Taxation, Asymmetric Taxation and Cross-Border Investment Incentives in Austria, July 2005

1507 Thomas Christiaans, Thomas Eichner and Ruediger Pethig, Optimal Pest Control in Agriculture, July 2005

1508 Biswa N. Bhattacharyay and Prabir De, Promotion of Trade and Investments between China and India: The Case of Southwest China and East and Northeast India, July 2005

1509 Jean Hindriks and Ben Lockwood, Decentralization and Electoral Accountability: Incentives, Separation, and Voter Welfare, July 2005 
1510 Michelle R. Garfinkel, Stergios Skaperdas and Constantinos Syropoulos, Globalization and Domestic Conflict, July 2005

1511 Jesús Crespo-Cuaresma, Balázs Égert and Ronald MacDonald, Non-Linear Exchange Rate Dynamics in Target Zones: A Bumpy Road towards a Honeymoon - Some Evidence from the ERM, ERM2 and Selected New EU Member States, July 2005

1512 David S. Evans and Michael Salinger, Curing Sinus Headaches and Tying Law: An Empirical Analysis of Bundling Decongestants and Pain Relievers, August 2005

1513 Christian Keuschnigg and Martin D. Dietz, A Growth Oriented Dual Income Tax, July 2005

1514 Fahad Khalil, David Martimort and Bruno Parigi, Monitoring a Common Agent: Implications for Financial Contracting, August 2005

1515 Volker Grossmann and Panu Poutvaara, Pareto-Improving Bequest Taxation, August 2005

1516 Lars P. Feld and Emmanuelle Reulier, Strategic Tax Competition in Switzerland: Evidence from a Panel of the Swiss Cantons, August 2005

1517 Kira Boerner and Silke Uebelmesser, Migration and the Welfare State: The Economic Power of the Non-Voter?, August 2005

1518 Gabriela Schütz, Heinrich W. Ursprung and Ludger Wößmann, Education Policy and Equality of Opportunity, August 2005

1519 David S. Evans and Michael A. Salinger, Curing Sinus Headaches and Tying Law: An Empirical Analysis of Bundling Decongestants and Pain Relievers, August 2005

1520 Michel Beine, Paul De Grauwe and Marianna Grimaldi, The Impact of FX Central Bank Intervention in a Noise Trading Framework, August 2005

1521 Volker Meier and Matthias Wrede, Pension, Fertility, and Education, August 2005

1522 Saku Aura and Thomas Davidoff, Optimal Commodity Taxation when Land and Structures must be Taxed at the Same Rate, August 2005

1523 Andreas Haufler and Søren Bo Nielsen, Merger Policy to Promote 'Global Players'? A Simple Model, August 2005

1524 Frederick van der Ploeg, The Making of Cultural Policy: A European Perspective, August 2005

1525 Alexander Kemnitz, Can Immigrant Employment Alleviate the Demographic Burden? The Role of Union Centralization, August 2005

1526 Baoline Chen and Peter A. Zadrozny, Estimated U.S. Manufacturing Production Capital and Technology Based on an Estimated Dynamic Economic Model, August 2005 
1527 Marcel Gérard, Multijurisdictional Firms and Governments' Strategies under Alternative Tax Designs, August 2005

1528 Joerg Breitscheidel and Hans Gersbach, Self-Financing Environmental Mechanisms, August 2005

1529 Giorgio Fazio, Ronald MacDonald and Jacques Mélitz, Trade Costs, Trade Balances and Current Accounts: An Application of Gravity to Multilateral Trade, August 2005

1530 Thomas Christiaans, Thomas Eichner and Ruediger Pethig, A Micro-Level 'Consumer Approach' to Species Population Dynamics, August 2005

1531 Samuel Hanson, M. Hashem Pesaran and Til Schuermann, Firm Heterogeneity and Credit Risk Diversification, August 2005

1532 Mark Mink and Jakob de Haan, Has the Stability and Growth Pact Impeded Political Budget Cycles in the European Union?, September 2005

1533 Roberta Colavecchio, Declan Curran and Michael Funke, Drifting Together or Falling Apart? The Empirics of Regional Economic Growth in Post-Unification Germany, September 2005

1534 Kai A. Konrad and Stergios Skaperdas, Succession Rules and Leadership Rents, September 2005

1535 Robert Dur and Amihai Glazer, The Desire for Impact, September 2005

1536 Wolfgang Buchholz and Wolfgang Peters, Justifying the Lindahl Solution as an Outcome of Fair Cooperation, September 2005

1537 Pieter A. Gautier, Coen N. Teulings and Aico van Vuuren, On-the-Job Search and Sorting, September 2005

1538 Leif Danziger, Output Effects of Inflation with Fixed Price- and Quantity-Adjustment Costs, September 2005

1539 Gerhard Glomm, Juergen Jung, Changmin Lee and Chung Tran, Public Pensions and Capital Accumulation: The Case of Brazil, September 2005

1540 Yvonne Adema, Lex Meijdam and Harrie A. A. Verbon, The International Spillover Effects of Pension Reform, September 2005

1541 Richard Disney, Household Saving Rates and the Design of Social Security Programmes: Evidence from a Country Panel, September 2005

1542 David Dorn and Alfonso Sousa-Poza, Early Retirement: Free Choice or Forced Decision?, September 2005 